\title{
Izzivi obvladovanja sprememb v laboratorijih
}

\author{
Milan Simončič* \\ Fakulteta za organizacijske študije v Novem mestu, Ulica talcev 3, 8000 Novo mesto, \\ Slovenija \\ milan.simoncic@fos-unm.si
}

\begin{abstract}
Povzetek:
Raziskovalno vprašanje (RV):. S kakšnimi tveganji in izzivi se srečujejo preskuševalni in kalibracijski laboratoriji, ob nadgradnji merilne opreme?

Namen: Raziskati, kako slovenski laboratoriji obvladujejo spremembe pri nadgradnji in/ali zamenjavi svoje merilne opreme.

Metoda: Za raziskavo smo razvili vprašalnik. $\mathrm{K}$ sodelovanju smo povabili predstavnike iz 86 kalibracijskih in preskuševalnih laboratorijev v Sloveniji. Za vrednotenje podatkov smo poleg opisne in frekvenčne statistike, uporabili Kruskal-Wallisov test.

Rezultati: Kot najpogostejši razlog za posodobitev merilne opreme so laboratoriji navedli dotrajanost, sledi povečanje kapacitet. Naložba $v$ novo merilno opremo je $v$ veliki večini upravičila pričakovanja. Prav tako smo potrdili, da je večina instalacij potekala korektno. Laboratoriji so bili po spremembi bolj učinkoviti, nova merilna oprema pa zagotavlja zanesljivejše rezultate merjenj. V manjšem deležu uvedene spremembe niso bile uspešne. Upoštevajoč število merilnih sistemov, število oseb, ki obvladuje laboratorijsko opremo in zahtevnost, nismo dokazali statistično značilnih razlik.

Organizacija: Slovenski laboratoriji se soočajo z enakimi izzivi in obvladujejo tveganja, kot primerljivi tuji laboratoriji, to je pomembno sporočilo raziskave.

Družba: Laboratoriji uvajajo nenehne spremembe in jih uspešno obvladujejo. To krepi zaupanje v poročane rezultate. Ti vplivajo na kakovost in sprejemljivost različnih produktov in storitev, podpirajo industrijske procese in so $\mathrm{v}$ funkciji monitoringa okolja.

Originalnost: Rezultati so neposredno uporabni in relevantni $\mathrm{v}$ slovenskem in mednarodnem prostoru. Gre za prvo takšno raziskavo v Sloveniji.

Omejitve/nadaljnje raziskovanje: Omejili smo se zgolj na spremembe, ki so v zvezi z merilno opremo. Nadaljnje raziskave lahko usmerimo $\mathrm{v}$ bolj poglobljeno analizo, s poudarkom na različne ravni obvladovanja in tudi drugih vplivov, npr. človeških virov. Prav tako bi lahko proučili odzive laboratorijev, ločeno za transakcijske in transformacijske spremembe.
\end{abstract}

Ključne besede: obvladovanje tveganj, obvladovanje sprememb, laboratorijska dejavnost, merilna oprema.

\section{Uvod}

Med spremembami, s katerimi se dnevno soočamo na vseh področjih, je tudi razvoj merilne opreme. Zaradi navedenega dejstva se organizacije nenehno spreminjajo, tudi tiste, katerih dejavnosti vključujejo preskušanje ali kalibriranje. Posodabljanje merilne opreme preskuševalnih in kalibracijskih laboratorijev, standardizacija, nižanje meja zaznavnosti določanih parametrov, težnja po večji natančnosti in točnosti ter vedno bolj celovit nadzor nad 
merjenjem so procesi, ki jih laboratoriji kontinuirano izvajajo. Procese sprememb v laboratorijih, $\mathrm{v}$ funkciji doseganja vedno višjih ciljev, želijo izvesti s sistematičnim načrtovanjem in z uvajanjem stalnih izboljšav. Glavni generator teh sprememb je nenehen tehnološki razvoj merilne opreme in programskih orodij (posledično zastarelost, nedobavljivost rezervnih delov in globalizacija). Spremembe v laboratorijih lahko spodbujata zakonodajalec ali naročnik, ki vplivata na kompleksnost izbranih analitskih pristopov in merilne tehnike. Laboratoriji spremembe izvajajo tudi zaradi standardizacije, ki spremlja proizvodne procese.

Ob vsaki izvedeni spremembi v laboratoriju obstaja določena stopnja tveganja. Pričakujemo, da novi merilni sistemi ali spremenjene/nadgrajene analitske metode ne poslabšujejo obstoječega stanja. Še več, tovrstne spremembe uvajamo s ciljem izboljšanja dobre laboratorijske prakse, višje razpoložljivosti merilne opreme in zanesljivejših rezultatov. Pomemben cilj v vsaki laboratorijski dejavnosti je vzdrževanje sistema kakovosti, ki bo učinkovit in robusten $v$ vseh okoliščinah delovanja. Uspešnost realizacije navedenega cilja se izraža s pravilnimi rezultati preskušanja, s čim manjšo merilno negotovostjo in obvladljivimi stroški za laboratorij in organizacijo.

Zanima nas, kako spremembe pri nadgradnji in/ali zamenjavi merilne opreme obvladujejo preskuševalni in kalibracijski laboratoriji v Sloveniji. Kakšna tveganja prepoznavajo v teh primerih in kako jih omejujejo?

$\mathrm{K}$ sodelovanju $\mathrm{v}$ raziskavi smo povabili preskuševalne laboratorije $\mathrm{z}$ akreditacijo po ISO 17025:2017, pri Slovenski akreditaciji. Omenjeni standard predpisuje splošne zahteve za usposobljenost preskuševalnih in kalibracijskih laboratorijev.

\section{Teoretična izhodišča}

Manuele (2012) utemeljuje, da je namen menedžmenta sprememb tudi opredelitev, analiza in ocena tveganja. Izpostavlja študije in primere, ki kažejo pomen načrtovanja in priprave sprememb pred uvedbo, v funkciji omejevanja tveganj in obvladovanja. (str. 35)

Tveganje lahko opredelimo kot odstopanje od pričakovanega. Obvladovati ga je potrebno v vseh delih organizacije, za kar je odgovoren vsak posameznik v organizaciji. Obvladovanje tveganj je sestavni del organizacijskega namena, upravljanja, vodenja in zavezanosti, strategije, ciljev in dejavnosti. (ISO 31000:2018, 2018, str. 1, 5)

Pri obvladovanju zahtevnejšega in večdimenzionalnega konkurenčnega okolja, več kot milijon organizacij po vsem svetu od leta 1987 uporablja standard ISO 9001 (Fonseca, 2015, str. 170). Standard ISO 9001 izhaja iz načel vodenja kakovosti uspešnih organizacij. V celoto povezuje dobre poslovne prakse in je v pomoč organizacijam pri doseganju najvišjih ciljev. Standard ISO 17025 pa je bil razvit s ciljem, da bi vzpodbudili zaupanje $\mathrm{v}$ delovanje laboratorijev. Preskuševalni in kalibracijski laboratoriji, ki delujejo skladno z ISO 17025, na splošno delujejo tudi po načelih ISO 9001 (ISO 17025:2017, 2018, str. 9). Najnovejši in trenutno veljavni reviziji mednarodnih standardov ISO 9001:2015 (Sistemi vodenja kakovosti) in ISO 17025:2017 
(Splošne zahteve za usposobljenost preskuševalnih in kalibracijskih laboratorijev) prinašata nove zahteve za obravnavo tveganj in priložnosti, katere je potrebno celovito obvladovati. (Fonseca, 2015, str. 174; ISO 17025:2017, 2018, str. 38)

Razmišljanje na podlagi tveganj je ena od posebnih novosti Mednarodne organizacije za standardizacijo. Standardi za obvladovanje tveganj ne predpisujejo nobenega specifičnega orodja. Nekatere organizacije so sprejele nekatera formalna orodja, pri tem so bolj ali manj uspešna. (Corpuz, 2020, str. 149)

Učinkovitost obvladovanja tveganj $\mathrm{v}$ laboratorijih je tesno povezana $\mathrm{z}$ menedžmentom organizacije in vodenjem. Žagarjeva (2017) za organizacije prepoznava sledeče dejavnike tveganj: vodenje, usklajenost pogledov na vizijo in cilje organizacije in (ne)zavedanje in (ne)poznavanje ali (ne)priznavanje delovnih pogojev, ki vplivajo na produktivnost organizacije. Vodstvo je najpomembnejši dejavnik v ustvarjanju uspešne organizacije in tako tudi vir tveganj. Zavedanje vodij o pomembnosti poznavanja svojih močnih področij in drugih kompetenc ter prepoznavanje in priznavanje šibkih področij, ki lahko vplivajo na uspešnost, je korak k dejanjem, s katerimi se ta lahko zmanjšajo ali preprečijo. Prav slednja so tista, ki jih vodje lahko uspešno kompenzirajo s pridobivanjem ustreznih znanj in veščin ali pa z vključitvijo ustrezno kompetentnih ljudi v delovanje organizacije. (str. 22-23)

Poleg menedžerjev in vodij, so za obvadovanje tveganj v laboratorijih odgovorni in pomembni tudi vsi ostali, sploh tisti, ki so neposredno vključeni v laboratorjisko dejavnost. Jayantha (2020) navaja, da mora biti upravljanje tveganj integrirano na vseh ravneh upravljanja in v vseh funkcijah organizacije. Vsi v organizaciji so odgovorni za upravljanje tveganj. Upoštevati morajo namen in cilje organizacije. Opravljanje dejavnosti vključuje tveganja in iskanje priložnosti za doseganje uspeha. Organizacija se ne bi smela zanašati samo na ublažitev tveganj, ampak bi morala spodbujati in olajšati učinkovito obvladovanje tveganj in priložnosti. Obstajajo različni standardi in okviri, ki podpirajo organizacije na področju upravljanja tveganj. Organizacije morajo izbrati najboljši okvir, ki ustreza njihovim ciljem, in jih prilagoditi svojim potrebam. (str. 366-370)

Upravljanje s tveganji v organizacijah postaja neločljiv element upravljanja, pravi Pacana (2018). Pri tem izpostavlja tudi pomembnost nadzora nad merilno opremo. Predlaga upravljanje tveganj po večstopenjski metodologiji, z namenom preprečevanja napačnih merjenj. Tveganja razvršča po pomembnosti in predpostavlja, da jih ni mogoče v celoti odpraviti. Za tveganja, ki predstavljajo grožnjo doseganju ciljev kakovosti, morajo biti sprejeti ustrezni ukrepi. Pomembno je, da za prepoznana tveganja, ki niso bila v celoti odpravljena, obstaja način spremljanja in nadzora. Dodaja, da je to mogoče storiti pred vodstvenimi pregledi oz. pred občasnimi pregledi upravljanja. Osnovni pogoj učinkovitosti sistema za obvladovanje tveganj za nadzor merilne opreme je njegova primernost za organizacijo. Podroben postopek ocenjevanja tveganj bo morda težko opraviti. Tveganje je posledica negotovosti, glede na pričakovane rezultate. (str. 10-11) 
Organizacije, ki v obsegu svoje dejavnosti izvajajo tudi (ali samo izključno) laboratorijsko dejavnost preizkušanja ali kalibriranja, so primorane $\mathrm{k}$ stalni nadgradnji in posodabljanju merilne opreme. Samo tako obstanejo v konkurenčnem okolju in delujejo uspešno. Podjetje Lab Manager, s sedežem v ZDA, je v marcu 2020 izvajalo raziskavo med obiskovalci njihove spletne strani. Ta je namenjena analitikom v laboratorijih, ki upravljajo z instrumenti za spektrofotometrijo, kromatografijo, masno spektrometrijo, NMR, elementarno analizo, TOC analizo, rentgensko analizo, določanje velikosti delcev, kalorimetrijo, potenciometrijo, viskozimetrijo, refraktometrijo, spektrofotometrijo, titracijo in tehtanje. Večina laboratorijev v analizni kemiji uporablja manjši ali večji nabor tovrstne opreme. Sodelujoči so izpostavili sledeče (Brown, 2020):

- vzdrževanje merilne opreme ima zelo pomembno vlogo pri zagotavljanju pravilnih rezultatov;

- približno $40 \%$ sodelujočih je poročalo, da vzdrževanje opreme pretežno zagotavljajo z lastnim osebjem, pri tem so jim najbolj v pomoč priročniki za uporabo;

- $36 \%$ sodelujočih uporabnikov za vzdrževanje uporablja izključno pooblaščene servise proizvajalcev opreme, kot slabe izkušnje pa so najpogosteje navedli visoke stroške pogodb za storitve vzdrževanja in počasen odziv nekaterih serviserjev;

- približno $84 \%$ sodelujočih načrtuje v bližnji prihodnosti kupiti vsaj en analitični instrument (najvišji odstotek sodelujočih bo kupilo analizator za tekočinsko kromatografijo);

- glavni razlog za nakup nove merilne opreme je zamenjava stare (47\%), sledita povečanje kapacitet obstoječih merilnih sistemov (36\%) in nabava povsem nove opreme $(8 \%)$;

- več kot $90 \%$ anketirancev se je strinjalo, da so najpomembnejši dejavniki, ki vplivajo na izbiro nove merilne opreme zanesljivost, natančnost in trpežnost;

- zelo pomemben dejavnik, ki ga upoštevajo pri nakupu analitičnih instrumentov, je tudi spremljajoča programska oprema, številni anketiranci so komentirali, kako pomembno je, da je uporabniku prijazna in kompatibilna $z$ analitičnimi instrumenti, opozorili so, da pogostost posodobitev programske opreme lahko moti njihov potek dela in bi želeli biti bolj obveščeni, ko so na voljo posodobitve;

- manj kot polovica jim meni, da so pri izbiri med najpomembnejšimi dejavniki tudi varnostne funkcije, garancijski pogoji in kompatibilnost z obstoječo opremo;

- še manj sodelujočih (24\%) smatra, da je pri izbiri merilne opreme pomemben dejavnih tudi velikost (zaradi omejenosti delovnih površin).

Serpa, Ferreira, \& Sá (2020) zagovarjajo stališče (kot tudi Mitchell \& Berlan, 2018), da lahko SWOT analiza, če je primerno izvedena, pomaga pri odločanju v profitnih ali neprofitnih organizacijah, vključno z obvladovanjem tveganj. Diagnostična ocena SWOT v svojo sistematično analizo vključuje perspektivno razsežnost za izboljšanje svoje učinkovitosti v organizacijski strategiji. (str. 93) Preskuševalni laboratorij v eni od slovenskih organizacij, ki izvaja akreditirano dejavnost in politiko kakovosti upravlja skladno s standardom ISO 17025:2017, je obravnavo tveganj in priložnosti izvedel s samoocenjevanjem, ki je vključevalo 
poglobljeno SWOT analizo. Pri vrednotenju prednosti, slabosti, priložnosti in nevarnosti, so se sistematično osredotočili na merilno opremo laboratorija. Med nevarnostmi so prepoznali tudi »hiter tehnološki napredek na področju merilne opreme in zahtevnejša programska orodja«. To so utemeljili na lastni študiji primera. V preteklosti je laboratorij namreč zamenjal dotrajano merilno opremo, instaliral novejšo in po zagotovilih dobavitelja zmogljivejšo, vendar ta ni zadovoljila želenih pričakovanj. Na splošno pa laboratorij ni imel slabih izkušenj z nadgradnjo svojih analitskih metod. (Simončič \& Žnideršič, 2019, str. 4-8)

\section{Metoda}

Na sliki 1 smo prikazali vplive in generatorje sprememb, ki jih morajo obvladovati uspešni preskuševalni in kalibracijski laboratoriji ter dejavnike, ki so odvisni od učinkovitosti izvedbe nadgradnje ali instalacije nove merilne opreme.

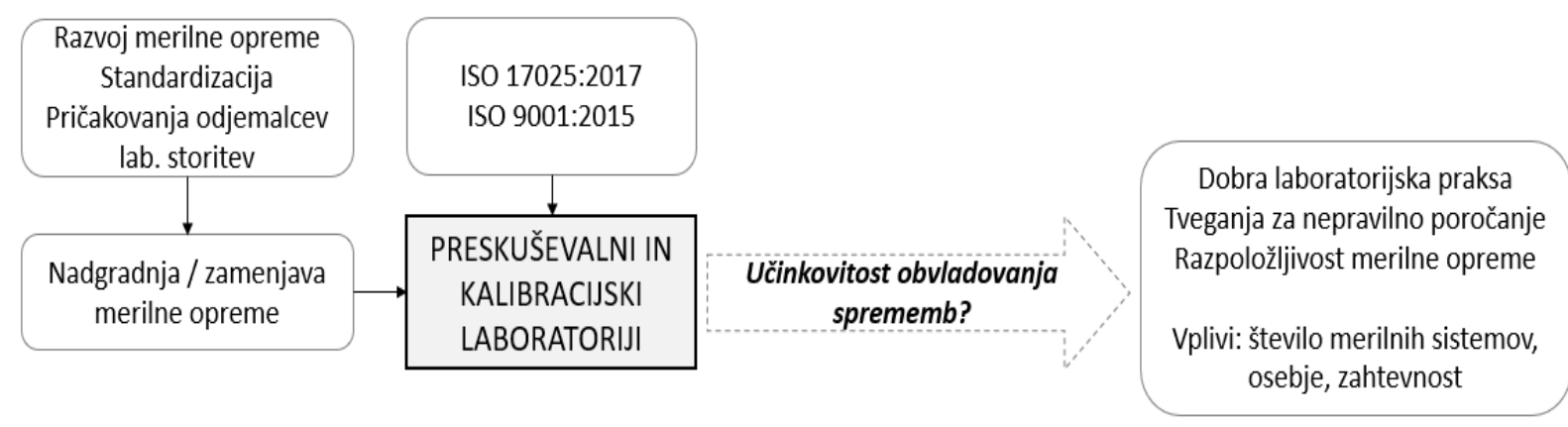

Slika 1. Slika raziskave.

V januarju 2021 smo k sodelovanju v raziskavi povabili 148 predstavnikov iz 86 kalibracijskih in preskuševalnih laboratorijev, ki v Republiki Sloveniji izvajajo akreditirano dejavnost skladno z ISO 17025 in so akreditirani pri Slovenski akreditaciji. Seznam akreditiranih organov in obsegi njihovih laboratorijskih akreditiranih dejavnosti, so javno objavljeni na spletni strani Slovenske akreditacije. Kontaktne podatke sodelujočih smo pridobili na uradnih spletnih straneh akreditiranih laboratorijev, oz. organizacij, za katere izvajajo svojo dejavnost. Sodelujoči so izpolnjevali spletno anketo, s katero smo ugotavljali, kako obvladujejo nadgradnjo ali zamenjavo merilne opreme in kako to vpliva na morebitna tveganja za poročane rezultate.

Uporabili smo objektivni merilni instrument, ki je v funkciji spremenljivk, ki smo jih merili. Za namen raziskave je bil razvit vprašalnik z 9 vprašanji zaprtega tipa. Zanesljivost vprašalnika smo preverili s testom Cronbach alfa. Po vrednotenju $(\alpha=0,728)$ smo zaključili, da je njegova zanesljivost dobra. Sodelujoči so izražali strinjanje s trditvami, pozvali smo jih, da se pri odgovorih osredotočijo na zadnjo izvedeno instalacijo ali nadgradnjo merilne opreme, ki so jo v laboratoriju izvedli. Dodatno smo sodelujočim postavili še vprašanja, na osnovi katerih smo ugotavljali, kdaj in kako pogosto izvajajo laboratorijske spremembe, obseg in zahtevnost merilne opreme, ki jo obvladujejo in število oseb, ki sodeluje v laboratorijski dejavnosti. Raziskava je ponovljiva, tako je mogoče preveriti njeno konsistentnost. Obseg ne odstopa 
bistveno od raziskave, ki jo je izvajalo ameriško podjetje Lab Manager. Pri analizi zbranih podatkov smo uporabili opisno in frekvenčno statistiko ter Kruskal-Wallisov test, s katerim smo ugotavljali statistično značilne razlike.

\section{Rezultati}

Od 4. 1. 2021 do 31. 1. 2021 smo pridobili podatke od 56 predstavnikov različnih slovenskih laboratorijev. 2 od sodelujočih laboratorijev sta svojo merilno opremo opredelila kot »manj zahtevno« za uporabo, 24 kot »srednje zahtevno«, 23 pa kot »zelo zahtevno«. Največ sodelujočih laboratorijev (19) ima v laboratorijsko delo vključenih do 5 analitikov, 8 laboratorijev pa več kot 20. Večina laboratorijev redno posodablja svojo merilno opremo, kar je razvidno iz slike 2. Večina (42) laboratorijev je v letu 2020 kupilo in instaliralo vsaj kakšen merilni sistem (33 od tega več kot enega). Samo 2 (manjša) laboratorija v zadnjih štirih letih nista izvedba nobene nove instalacije oz. nista posodobila svoje merilne opreme.

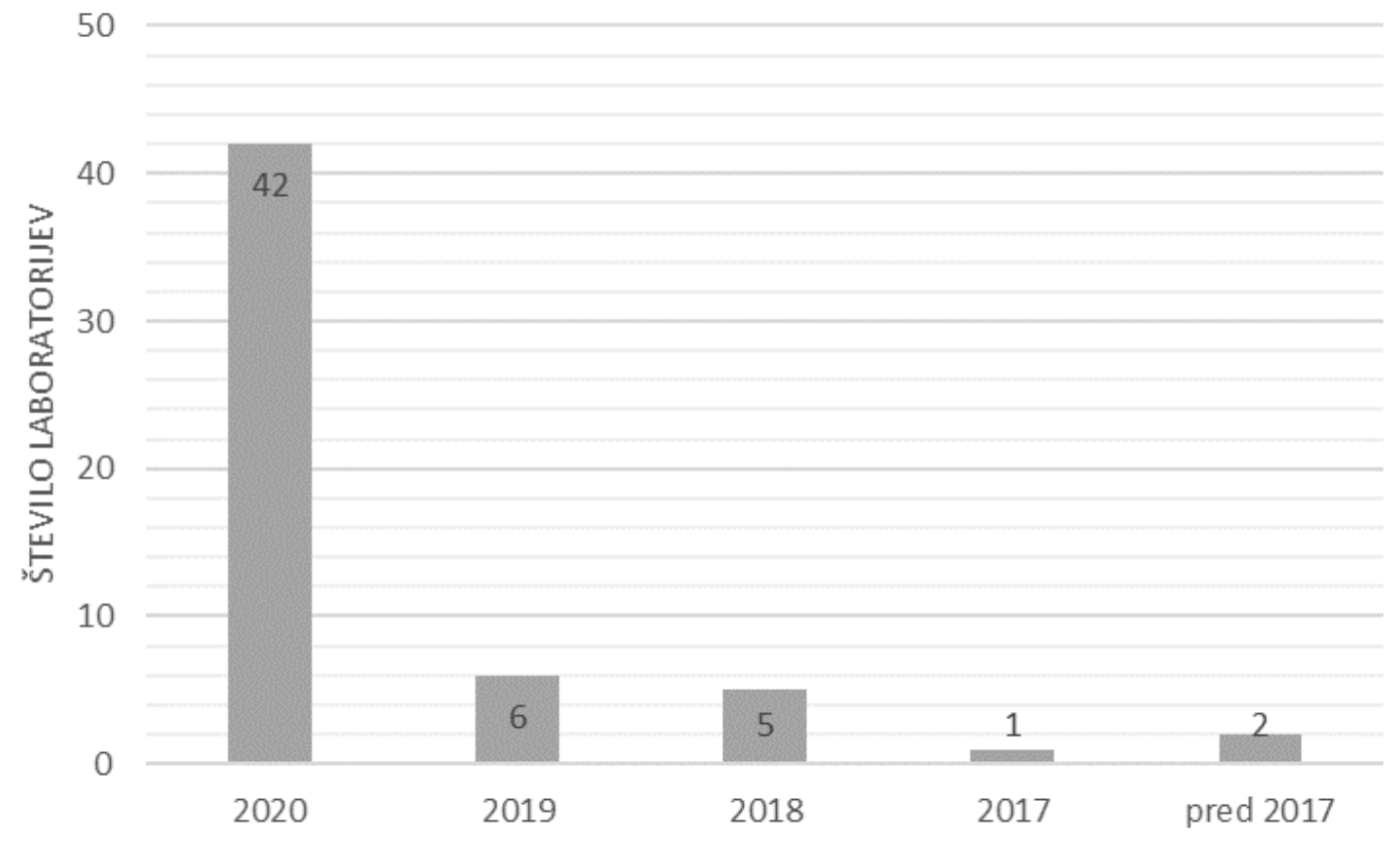

Slika 2. Leto zadnje posodobitve merilne opreme.

Kot najpogostejši povod za posodabljanje merilne opreme, so sodelujoči navedli dotrajanost obstoječih sistemov (v 44,2 \% primerih). Sledijo posodobitve zaradi povečanja kapacitet laboratorija (kjer izstopajo večji laboratoriji in tisti, ki obvladujejo zelo zahtevno opremo), potreba za novo analizno metodo, nezadovoljstvo z obstoječo opremo $(7,7 \%)$, v enem primeru pa nabava manj zahtevne opreme. Kot druge razloge je 5 sodelujočih navedlo opustitev dejavnosti in nezadovoljstvo s servisom oz. podporo proizvajalca, slika 3.

Na sliki 4 je razviden delež strinjanja in popolnega strinjanja s ponujenimi 9 trditvami. V prepričljivi večini so naložbe v novo merilno opremo upravičile pričakovanja, postopki izbire in instalacije so potekali po pričakovanjih, nova merilna oprema pa je prispevala $\mathrm{v}$ večji 
učinkovitosti laboratorija in zagotavlja zanesljivejše rezultate. Za okvirno polovico instalacij in posodobitev velja, da je sprememba zahtevala veliko dodatnih človeških virov, za postavitev novih ali prilagajanja obstoječih analiznih postopkov. V $67 \%$ velja, da je nova merilna oprema zmanjšala tveganja za podajanje nepravilnih rezultatov merjenj.

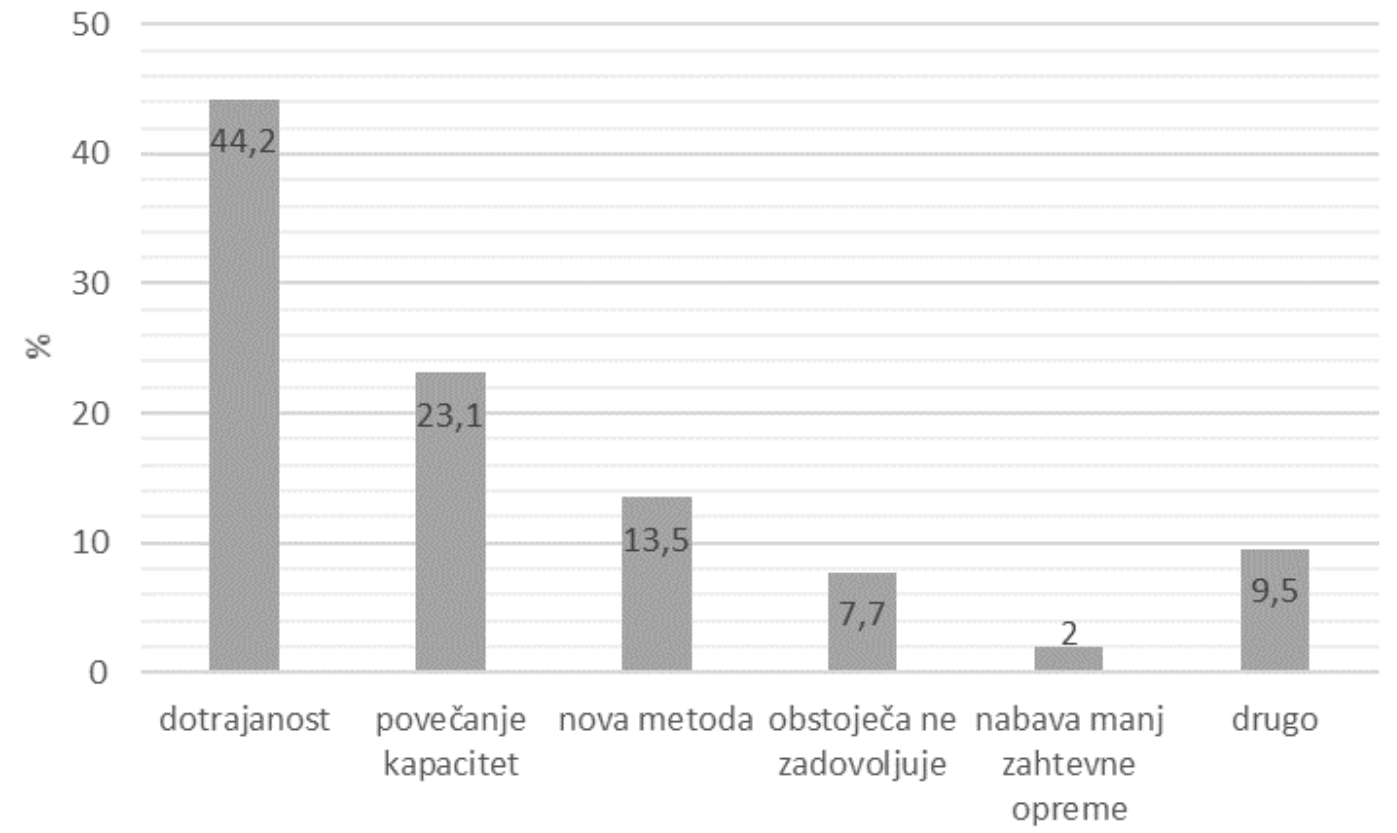

Slika 3. Razlog zadnje posodobitve merilne opreme. 


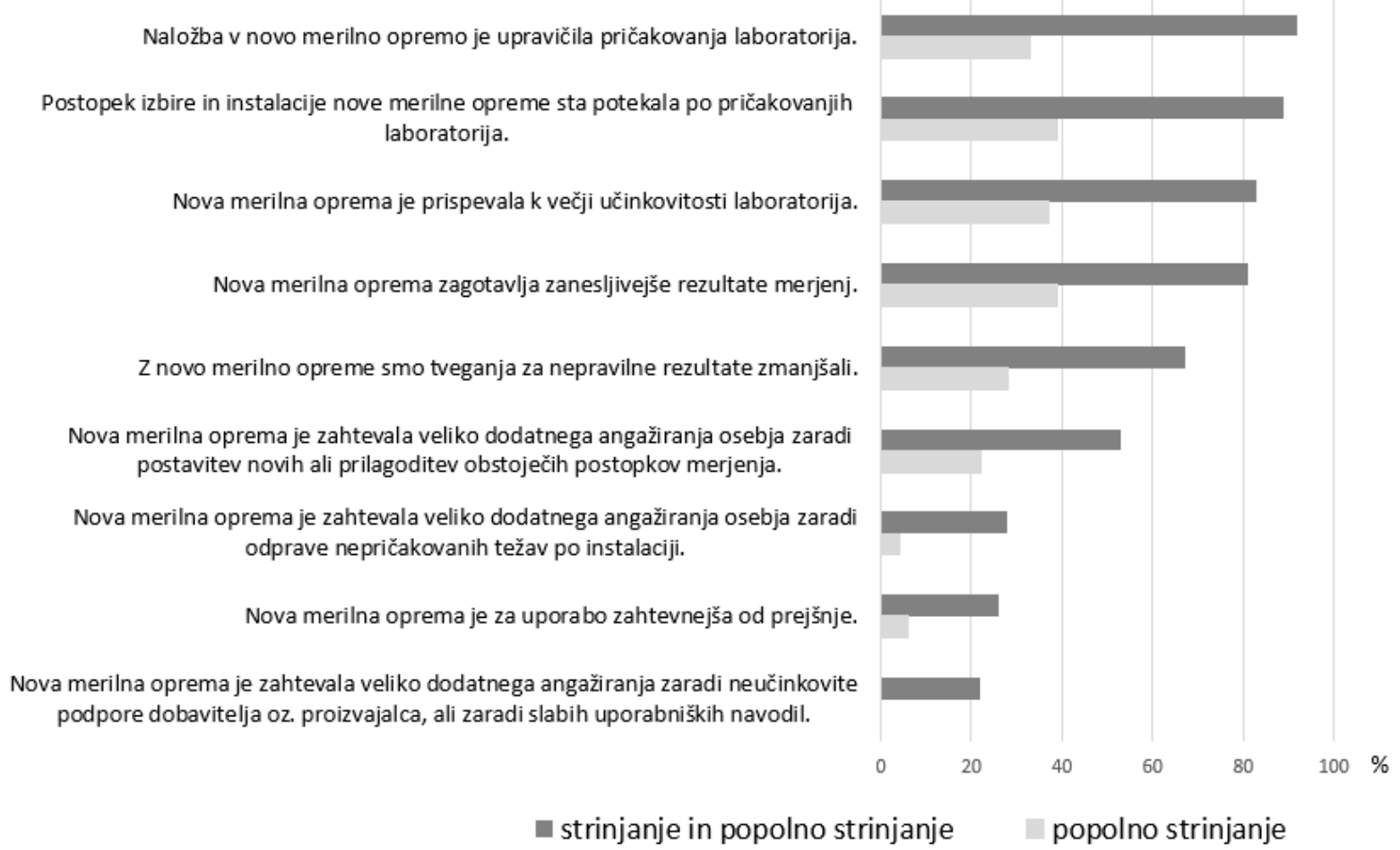

Slika 4. Delež strinjanja in popolnega strinjanja s trditvami.

Sodelujoči so imeli možnost izbrati največ 3 vplivne dejavnike, ki so zanje najbolj pomembni pri izbiri nove merilne opreme (slika 5). Skoraj vsi so na 1. mesto postavili »zanesljivost in natančnost nove merilne opreme«. Sledijo ostali dejavniki, kot npr. »razmerje med ceno in zmogljivostjo«, »navodila za uporabo, usposabljanje in servis«, »prijazna programska oprema« in drugo.

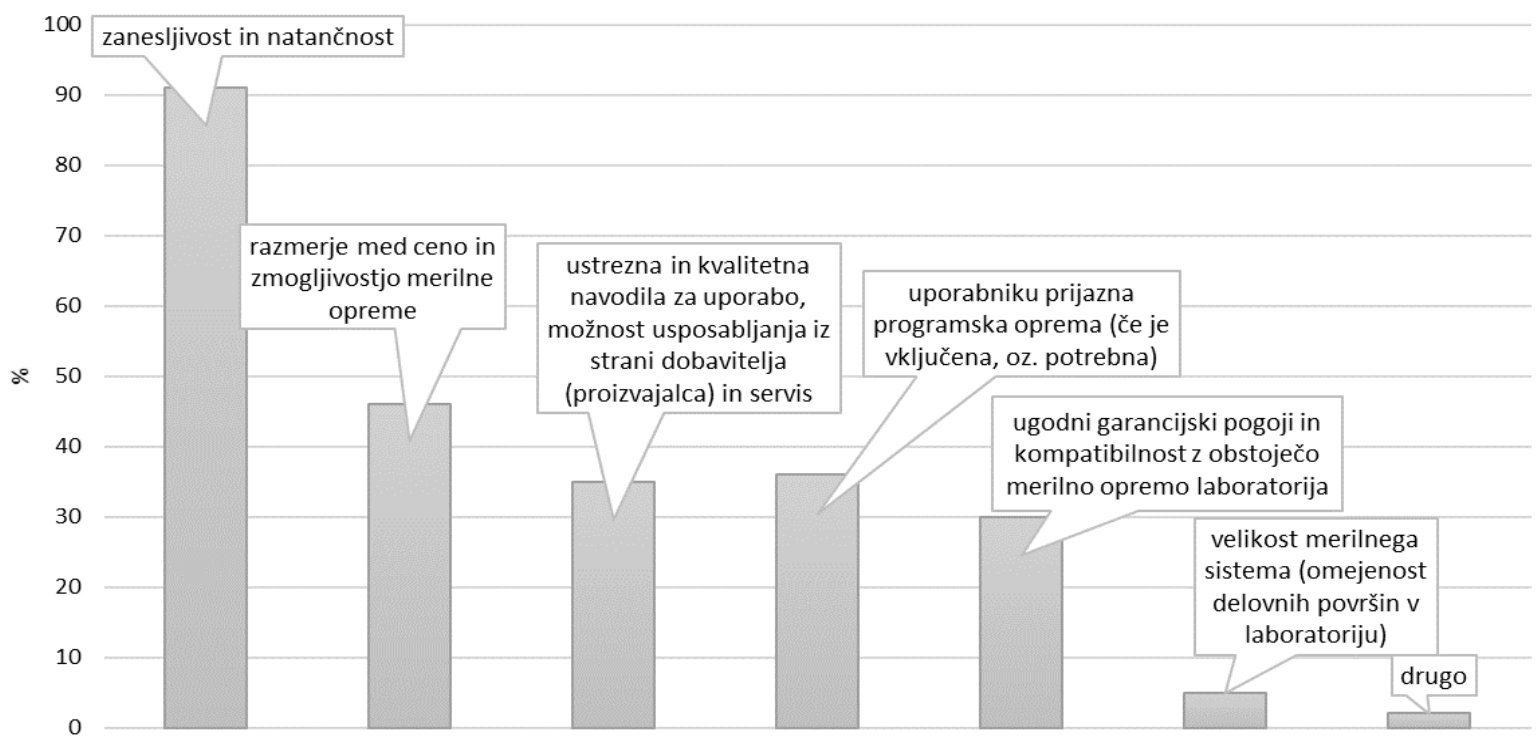

Slika 5.Vplivni dejavniki, ki jih uporabniki najbolj upoštevajo pri izbiri nove merilne opreme.

Ugotavljali smo še, kako na strinjanje s postavljenimi trditvami vplivajo število merilnih sistemov, ki jih laboratoriji obvladujejo (obseg dejavnosti), število oseb, ki dela z merilno 
opremo in zahtevnost uporabe merilne opreme. Za nobeno trditev nismo dokazali statistično značilnih razlik, ki bi potrdile vpliv omenjenih delavnikov. Rezultate smo navedli v tabeli 1.

Tabela 1. Kruskal-Wallisov test, upoštevajoč število merilnih sistemov, oseb in zahtevnost opreme.

\begin{tabular}{|c|c|c|c|c|}
\hline Trditev & & $d f$ & $\boldsymbol{H}$ & $p$ \\
\hline \multirow{3}{*}{$\begin{array}{l}\text { Postopek izbire in instalacije nove merilne opreme sta } \\
\text { potekala po pričakovanjih laboratorija. }\end{array}$} & število merilnih sistemov & 2 & 0,449 & 0,799 \\
\hline & število oseb & 3 & 5,256 & 0,154 \\
\hline & zahtevnost opreme & 2 & 2,122 & 0,346 \\
\hline \multirow{3}{*}{$\begin{array}{l}\text { Nova merilna oprema je zahtevala veliko dodatnega } \\
\text { angažiranja osebja zaradi postavitev novih ali } \\
\text { prilagoditev obstoječih postopkov merjenja. }\end{array}$} & število merilnih sistemov & 2 & 1,522 & 0,467 \\
\hline & število oseb & 3 & 3,144 & 0,370 \\
\hline & zahtevnost opreme & 2 & 0,845 & 0,656 \\
\hline \multirow{3}{*}{$\begin{array}{l}\text { Nova merilna oprema je zahtevala veliko dodatnega } \\
\text { angažiranja osebja zaradi odprave nepričakovanih } \\
\text { težav po instalaciji. }\end{array}$} & število merilnih sistemov & 2 & 0,127 & 0,939 \\
\hline & število oseb & 3 & 1,269 & 0,736 \\
\hline & zahtevnost opreme & 2 & 1,798 & 0,407 \\
\hline \multirow{3}{*}{$\begin{array}{l}\text { Nova merilna oprema je zahtevala veliko dodatnega } \\
\text { angažiranja zaradi neučinkovite podpore dobavitelja } \\
\text { oz. proizvajalca, ali zaradi slabih uporabniških } \\
\text { navodil. }\end{array}$} & število merilnih sistemov & 2 & 0,096 & 0,953 \\
\hline & število oseb & 3 & 1,550 & 0,671 \\
\hline & zahtevnost opreme & 2 & 4,889 & 0,087 \\
\hline \multirow{3}{*}{$\begin{array}{l}\text { Nova merilna oprema je za uporabo zahtevnejša od } \\
\text { prejšnje. }\end{array}$} & število merilnih sistemov & 2 & 0,837 & 0,658 \\
\hline & število oseb & 3 & 3,819 & 0,282 \\
\hline & zahtevnost opreme & 2 & 3,313 & 0,191 \\
\hline \multirow{3}{*}{$\begin{array}{l}\text { Naložba v novo merilno opremo je upravičila } \\
\text { pričakovanja laboratorija. }\end{array}$} & število merilnih sistemov & 2 & 2,661 & 0,264 \\
\hline & število oseb & 3 & 6,884 & 0,076 \\
\hline & zahtevnost opreme & 2 & 3,258 & 0,196 \\
\hline \multirow{3}{*}{$\begin{array}{l}\text { Nova merilna oprema je prispevala k večji } \\
\text { učinkovitosti laboratorija. }\end{array}$} & število merilnih sistemov & 2 & 3,900 & 0,142 \\
\hline & število oseb & 3 & 5,365 & 0,130 \\
\hline & zahtevnost opreme & 2 & 1,857 & 0,395 \\
\hline \multirow{3}{*}{$\begin{array}{l}\text { Nova merilna oprema zagotavlja zanesljivejše } \\
\text { rezultate merjenj. }\end{array}$} & število merilnih sistemov & 2 & 2,541 & 0,281 \\
\hline & število oseb & 3 & 6,840 & 0,077 \\
\hline & zahtevnost opreme & 2 & 4,737 & 0,093 \\
\hline \multirow{3}{*}{$\begin{array}{l}\mathrm{Z} \text { novo merilno opreme smo tveganja za nepravilne } \\
\text { rezultate zmanjšali. }\end{array}$} & število merilnih sistemov & 2 & 1,969 & 0,374 \\
\hline & število oseb & 3 & 6,143 & 0,105 \\
\hline & zahtevnost opreme & 2 & 4,099 & 0,129 \\
\hline
\end{tabular}

Opomba. $d f$ : prostostna stopnja; $H$ : K-W testna statistika; $p$ : statistična značilnost $(p<0,05$ pomeni, da obstaja statistično značilna razlika).

\section{Razprava}

Natančnost, točnost in pravočasnost poročanja izmerjenih rezultatov, kot produktov laboratorijskih merjenj, pomembno vplivajo na kakovost končnega izdelka ali sprejemanje pravilnih odločitev. Če navedemo samo konkreten primer iz medicine: laboratorijski izdatki običajno predstavljajo manj kot $5 \%$ večine bolnišničnih proračunov, vendar pa je pomen laboratorijskih meritev veliko večji, laboratorijski testi namreč vplivajo na $60 \%$ do $70 \%$ vseh zdravstvenih odločitev (Eaton et al., 2017, str. 1833). Zelo pomembno je, da laboratorijska oprema deluje $\mathrm{z}$ optimalno učinkovitostjo za doseganje najbolj zanesljivih rezultatov. Analogijo bi lahko, poleg medicine, navedli tudi za primere monitoringa okolja, pridelavo zdrave hrane, farmacijo, raziskovalne laboratorije in za številne industrijske procese. 
V začetku leta 2021 smo izvedli raziskavo, v kateri so sodelovali slovenski preskuševalni in kalibracijski laboratoriji. Zanimalo nas je, kako obvladujejo spremembe pri nadgradnji in/ali zamenjavi svoje merilne opreme in zagotavljajo zaupanja vredne rezultate. Raziskava odgovarja na vprašanja, s katerimi se soočamo pri tehnoloških spremembah merilne opreme in celovitem upravljanju kakovosti v laboratorijski dejavnosti. Pokazala je, da slovenski laboratoriji redno skrbijo za nadgradnjo svoje merilne opreme in uvajajo stalne izboljšave. S tem nadgrajujejo standarde in dvigujejo kakovost svojih storitev. Njihovo odzivanje na nenehen tehnološki razvoj in pozicioniranje na zahtevnem konkurenčnem trgu, je primerljivo $\mathrm{z}$ laboratoriji, ki so bili vključeni v ameriško raziskavo, ki jo je izvedlo podjetje Lab Manager.

Upravljanje s tveganji, v okolju nenehnih sprememb v organizacijah, postaja pomemben element upravljanja. Mednarodna standarda ISO 9001:2015 in 17025:2017 uvajata nove zahteve za obravnavo tveganj in priložnosti. Slovenski laboratoriji, ki vsaj del svojih merjenj izvajajo v sklopu akreditirane dejavnosti, tveganja uspešno obvladujejo. V veliki večini, z naložbo $\mathrm{v}$ novo merilno opremo ali nadgradnjo analitskih metod, zadovoljujejo svoja pričakovanja in povečujejo svojo učinkovitost, uvedene spremembe pa vplivajo na bolj zanesljive rezultate.

Okvirno vsaka druga nova instalacija merilne opreme zahteva dodatno ali večje angažiranje človeških virov, vsaj za nekaj časa, ko je razglašena polna operabilnost nove ali nadgrajene analitske metode. Pričakovanja neposrednih in posrednih odjemalcev laboratorijskih storitev so vedno višja, merilna oprema pa vedno bolj avtomatizirana in kompleksna. Obvladovanje laboratorijskih sprememb zahteva učinkovito vodenje laboratorijev, podporo in razumevanje vrhnjega menedžmenta organizacije.

Postopki izbire nove merilne opreme in vzpostavitve za delovanje, v slovenskih laboratorijih potekajo po pričakovanjih za večino realiziranih instalacij. To kaže na visoko strokovnost ne le izvajalcev laboratorijskih storitev, temveč tudi ponudnikov merilne opreme in strokovnih podpornih služb (pooblaščeni servisi). Konkurenčnost na zahtevnem trgu ponudnikov merilne opreme je tukaj v prid izvajalcem laboratorijskih storitev.

V manjšem deležu izvedenih sprememb, so se v laboratorijih tveganja za nepravilno poročanje rezultatov vendarle tudi povečala. Razlogi za to so bili po mnenju sodelujočih različni. Nekateri so navedli, da nova oprema zahteva znatno dodatno angažiranje osebja zaradi postavitve novih metod, zaradi odprave nepričakovanih zapletov pri instalaciji, zaradi večje zahtevnosti analizatorjev ali zaradi manjše zanesljivosti rezultatov, kot posledice drugih vplivov. Pomembno je, da so laboratoriji ta tveganja prepoznali in ovrednotili, predvidevamo, da so uvedli tudi potrebne korektivne ukrepe za odpravo prepoznanih odstopanj.

Upoštevajoč število merilnih sistemov, število oseb, ki izvaja merjenja in zahtevnost analitskih metod, rezultati niso pokazali statistično značilnih razlik. S podobnimi izzivi se torej soočajo vsi, ki izvajajo laboratorijsko dejavnost. 


\section{Zaključek}

Slovenski preskuševalni in kalibracijski laboratoriji se soočajo z enakimi izzivi, tveganji in hotenji, kot primerljivi tuji laboratoriji, to je pomembno sporočilo raziskave. Pomembno sporočilo izvedene raziskave je, da se slovenski preskuševalni in kalibracijski laboratoriji, ki vsaj del svojih nalog izvajajo kot akreditirano dejavnost, uspešno prilagajo spremembam in jih uspešno obvladujejo. Redno posodabljajo svojo merilno opremo in uvajajo izboljšave, podobno kot primerljivi laboratoriji v tujini. Odzivajo se na tehnološki napredek, nadomeščajo zastarelo merilno opremo in povečujejo svojo kapaciteto. Naložba v novo merilno opremo, v zadnjih treh letih, je v prepričljivi večini upravičila pričakovanja laboratorijev. Prav tako je za skoraj enak delež raziskava potrdila, da so nove instalacije in izbira merilne opreme potekale po pričakovanjih laboratorijev. V le manjšem deležu uvedene spremembe, po mnenju uporabnikov, niso bile uspešne.

Nove instalacij in posodobitve $\mathrm{v}$ laboratorijih prispevajo $\mathrm{k}$ večji učinkovitosti, nova merilna oprema pa zagotavlja zanesljivejše rezultate merjenj. To je pomembno sporočilo za organizacije, kakor tudi za širšo družbo, ki ob tem prepoznava dodano vrednost pri kakovosti izvedene storitve, izdelka ali zaupanju v poročani rezultat, na osnovi katerega se sprejemajo različne odločitve.

Rezultati so neposredno uporabni in relevantni v slovenskem in mednarodnem prostoru. Gre za prvo tovrstno raziskavo $\mathrm{v}$ Sloveniji.

Proučili smo zgolj določene in omejene vidike obvladovanja sprememb v preskuševalnih in kalibracijskih laboratorijih. Pri tem smo se omejili na laboratorijsko opremo. Nadaljnje raziskave lahko usmerimo $\mathrm{v}$ bolj poglobljeno analizo, s poudarkom na različnih ravneh obvladovanja: na osebni, skupinski in organizacijski. Prav tako bi lahko podrobneje analizirali organizacijske spremembe v laboratorijih iz vidika obvladovanja človeških virov ter odzivanje laboratorijev v primeru transakcijskih (postopnih, evolucijskih) in transformacijskih (enkratnih, radikalnih) sprememb.

\section{Reference}

1. Brown, C. C. (30. 3. 2020). Results from the Lab Manager Analytical Instrument Survey. Pridobljeno na Lab Manager: https://www.labmanager.com/surveys/results-from-the-labmanager-analytical-instrument-survey-22109

2. Corpuz, R. S. (2020). ISO 9001:2015 Risk-based Thinking: A Framework using Fuzzy-Support Vector Machine. Makara Journal of Technology, 24(3), 149-159. doi: 10.7454/mst.v24i3.3944

3. Eaton, K. P., Levy, K., Soong, C., Pahwa, A. K., Petrilli, C., \& Ziemba, J. B. (2017). EvidenceBased Guidelines to Eliminate Repetitive Laboratory Testing. JAMA Internal Medicine, 177(12), 1833-1839.

4. Fonseca, L. M. (2015). From quality gurus and TQM to ISO 9001:2015: A review of several quality paths. International Journal for Quality Research, 9(1), 167-180. 
5. ISO 31000:2018, Risk management - Guideline, Second edition. (2018). Geneva: ISO.

6. Jayantha, C. (2020). An Overview of ISO 31000: 2018 Risk Management and Role of Chartered Accountants. The Chartered Accountant, 69(03), 363-370.

7. Manuele, F. A. (2012). Management of Change, Examples from Practice. Professional Safety, 57(7), 35-43.

8. Mitchell, G. E., \& Berlan, D. (2018). Evaluation in nonprofit organizations: An empirical analysis. Public Performance \& Management Review, 41(2), 415-437. doi: 10.1080/15309576.2017.1400985

9. Pacana, A. (2018). Supervision of measuring equipment based on risk management and ISO 9001. Production Engineering Archives, 21, 8-11. doi: 10.30657/pea.2018.21.02

10. Serpa, S., Ferreira, C. M., \& Sá, M. J. (2020). The Potential of Organisations' SWOT Diagnostic Assessment. Academic Journal of Interdisciplinary Studies, 9(4), 93-104. doi: 10.36941/ajis2020-0065

11. Simončič, M., \& Žnideršič, J. (2019). Tveganja in priložnosti pri monitoringu tekočih in plinastih efluentov, Samovrednotenje, 2/2019 (interni dokument). Krško: Nuklearna elektrarna Krško.

12. Slovenska akreditacija. (11. december 2020). Slovenska akreditacija. Pridobljeno na Akreditirani organi: https://www.slo-akreditacija.si/

13. Splošne zahteve za usposobljenost preskuševalnih in kalibracijskih laboratorijev (ISO/IEC 17025:2017). (2018). Ljubljana: Slovenski inštitut za standardizacijo.

14. Žagar, T. (2017). Vodstvo, tveganja in priložnosti. Obvladovanje tveganj, 23. letna konferenca (str. 22-23). Murska Sobota: Pomursko društvo za kakovost.

$$
* * *
$$

Milan Simončič je diplomiral na Fakulteti za kemijo in kemijsko tehnologijo v Mariboru. Na Fakulteti za organizacijske študije $\mathrm{v}$ Novem mestu je pridobil naziv doktorja znanosti s področja menedžmenta kakovosti. Na Fakulteti za organizacijske študije v Novem mestu je bil izvoljen v naziv docenta. Zaposlen je v Nuklearni elektrarni Krško, kot vodja Kemije. Objavil je več člankov, aktivno deluje v strokovnih domačih in mednarodnih organizacijah. Raziskovalno se ukvarja s proučevanjem koncepta družbene odgovornosti, izzivov organizacijske odličnosti, priložnosti energetike v trajnostni družbi, sistemov vodenja kakovosti in kemije vodnih medijev jedrskih elektrarn.

\section{Abstract: \\ Challenges of Managing Changes in Laboratories}

Research Question (RQ): What risks and challenges testing and calibration laboratories face when upgrading measuring equipment?

Purpose: Investigate how Slovenian laboratories manage changes in the upgrade and/or replacement of their measuring equipment.

Method: As a tool for obtaining the necessary information, we used a questionnaire developed for this purpose. In addition to descriptive and frequency statistics, we used Kruskal-Wallis tests to evaluate the data.

Results: As the most frequently cited reason for the modernization of measuring equipment, they stated wear and tear, followed by an increase in capacity. The vast majority of investment in new measuring equipment was in line with expectations. We confirmed that most of the installations went correctly. The laboratories were more efficient after the change, and the new measuring equipment provides more reliable measurement results. To a smaller extent, the introduced changes were not successful. Considering the number of measuring systems, the number of persons dealing the laboratory equipment and the complexity, we did not prove statistically significant differences. 
Revija za univerzalno odličnost / Journal of Universal Excellence,

September 2021, leto / year 10, številka / number 3, str. / pp. 204-216.

Organization: Slovenian laboratories face the same challenges and manage risks as comparable foreign laboratories, which is an important message of the research.

Society: Laboratories introduce constant changes and successfully manage them. This strengthens confidence in the reported results. These affect the quality and acceptability of various products and services, support industrial processes and are in the function of monitoring the environment.

Originality: The results are directly useful and relevant in Slovenia and internationally. This is the first such research in Slovenia.

Limitations / further research: We have limited to changes related to measuring equipment. Further research can be focused on a more in-depth analysis, focusing on different levels of management as well as other impacts, e.g. human resources. Laboratory responses could also be examined separately for transactional and transformational changes.

Keywords: risk management, change management, laboratory activity, measuring equipment.

Copyright (c) Milan SIMONČIČ

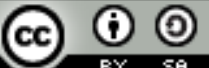

Creative Commons License

This work is licensed under a Creative Commons Attribution-ShareAlike 4.0 International License. 